\title{
MANIPULASI LINGKUNGAN UNTUK PEMIJAHAN IKAN HIAS RASBORA (Argyrotaenia Sp) DI WADAH TERKONTROL
}

\author{
${ }^{1)}$ Nurhidayat \\ ${ }^{1)}$ Balai Penelitian dan Pengembangan Budidaya Ikan Hias Depok \\ Jl. Perikanan No. 13 Pancoranmas, Kota Depok Jawa-Barat \\ Tlp/Fax : 021-7520482, e-mail : nhmasdayat@gmail.com
}

\begin{abstract}
ABSTRAK
Rasbora sp. merupakan salah satu ikan hias air tawar Indonesia yang mempunyai nilai ekonomis penting. Sampai saat ini pemenuhan kebutuhan pasar masih mengandalkan hasil tangkapan dari alam. Permintaan Rasbora sp. yang terus meningkat dapat mengakibatkan berkurangnya sumberdaya di alam bahkan bisa mengalami kepunahan. Penelitian ikan hias ini dilakukan untuk menjawab kebutuhan teknologi dalam memenuhi permintaan pasar ikan Rasbora sp. untuk menghindari kepunahan plasma nutfah. Tujuan penelitian ini adalah untuk melihat pertumbuhan, kematangan gonad dan reproduksi ikan Rasbora axelrodi yang dipelihara dalam substrat berbeda. Satuan percobaan yang digunakan dalam penelitian ini adalah: A. Eichornia crassipes, B. hidryla, C. melati air dan D. tali plastik. Parameter yang diamati meliputi pertumbuhan kematangan gonad, reproduksi dan kualitas air. Ikan yang dipelihara menunjukkan kematangan gonad yang sempurna sehingga terjadi pemijahan. Hasil pemeliharaan larva yang dilakukan selama penelitian menunjukkan pertambahan panjang tertinggi diperoleh perlakuan A. $1.46 \mathrm{~cm} /$ ekor, diikuti perlakuan D. $0.85 \mathrm{~cm}$, B. $0.70 \mathrm{~cm} /$ ekor dan C. $0.44 \mathrm{~cm} /$ ekor. Sedangkan pertumbuhan bobot tertinggi diperoleh perlakuan B. dan C dengan berat 0.07 gram/ekor diikuti A. 0.06 gram/ekor dan D. 0.04 gram/ekor. Selama pemeliharaan diperoleh nilai sintasan yang diperoleh di akhir penelitian yaitu melati air $83.33 \%$ diikuti oleh hidryla $80.6 \%$, enceng gondok $53.3 \%$ dan tali rafia 47.8\%. Tingkat kematangan gonad ikan Rasbora tertinggi diperoleh perlakuan dengan melati air, hidryla, enceng gondok dan tali ravia. Bulan kelima pemeliharaan ikan dengan mealti air memijah namun benih yang dihasilkan masih sedikit. Kualitas air selama pemeliharaan masih dalam kisaran yang baik untuk ikan Rasbora sp.
\end{abstract}

Kata Kunci : Manipulasi, kematangan gonad, pemijahan

\section{PENDAHULUAN}

Rasbora (Rasbora axelrodi) merupakan salah satu ikan hias air tawar yang memiliki ukuran relatif kecil dengan panjang tubuh berkisar $\pm 4.5 \mathrm{~cm}$, ikan ini masuk ke dalam famili Cyprinidae. Ikan ini banyak ditemukan tersebar di daerah semenanjung Malaka, Thailand dan Sumatera bagian timur (Simon dan Schuster, 2005). Morfologi ikan rasbora berbentuk langsing dan pipih dapat bergerak cepat dan mempunyai warna yang bervariasi sehingga cocok dikelompokkan ke dalam ikan hias karena corak warna, bentuk dan jenisnya (Mills, 2000).

Daerah penyebaran pada umumnya berupa sungai-sungai kecil dan besar, danau, genangan pinggir jalan dan persawahan, di air deras ikan ini tidak ditemukan. Habitat ikan ini mempunyai kisaran $\mathrm{pH}$ yang rendah, sehingga biasa hidup didaerah dengan pelindung berupa rerumputan dan serasah atau daun yang berguguran sehingga mempunyai $\mathrm{pH}$ rendah sekitar 5.5. Beberapa jenis ikan Rasbora axelrodi seperti $R$. pauciperformata, $R$. hetemorpha, $R$. dorciocellata dan $R$. maculata hidup di saluran persawahan, kolam kecil dan genangan pinggir jalan (Britan, 1953). Ikan ini hidup normal pada kisaran suhu $24-25^{\circ} \mathrm{C}$, dengan hidup secara bergerombol untuk mencari makan dan mempertahankan diri dari predator. Termasuk dalam kelompok omnivora senang makan cacing, serangga dan lumut serta 
mempunyai kebiasaan menempelkan telurnya di balik dedaunan atau rerumputan selama proses reproduksinya (Simon dan Schuster, 2005).

Perkembangan gonad ikan akan dipengaruhi oleh beberapa factor antara lain suhu, pakan, periode cahaya dan musim (Scoot, 1979). Selain factor tersebut pemijahan iken juga memerlukan tempat untuk meneplekkan telur sehingga aman dsari gangguan predator dan bisa menetas samapai menjadi larva dan benih. Tanaman air menyebabkan mata dan indera peraba melihat objek kemudian diteruskan Lobus optikus dan merangsang hipothalmus untuk memerintahkan kelenjar endokrin untuk menghasilkan kelejar endokrin untuk menghasilkan hormone yang merangsang untuk melakukan pemijahan.

Ikan ini sudah di domestikasikan tetapi pembenihan dan dipelihara hingga menghasilkan benih. Masalah yang dihadapi adalah induk yang digunakan masih belum bisa memijah. Diharapkan dengan menggunakan substrat yang dikondisikan seperti di habitatnya ikan rasbora bisa bereproduksi sampai memijah dan menghasilkan benih. Tujuan penelitian ini adalah untuk mengetahui pengaruh berbagai substrat terhadap pematangan gonad dan pemijahan ikan Rasbora sp.

\section{METODOLOGI PENELITIAN.}

Ikan Rasbora axelrodi yang digunakan untuk penelitian adalah ikan hasil tangkapan langsung dari alam. Sebelum dilakukan treatment ikan diadaptasikan terlebih dahulu di wadah budidaya selama satu bulan kemudian baru siap untuk diberi perlakuan.

\section{Satuan Percobaan}

Wadah pemeliharaan berupa akuarium dengan ukuran 90x50x40 cm diisi dengan 50 liter air, masingmasing perlakuan diulang sebanyak empat kali. Masing-masing akuarium diisi dengan ikan Rasbora axelrodi dengan kepadatan 1 ekor per liter. Perlakuan yang diberikan adalah A. tanaman air, B. enceng gondok, C. tali plastik dan D. Kontrol (ganggang).

\section{Variabel Kerja :}

Variable kerja yang diamati untuk penelitian ini adalah : kematangan gonad, fekunditas dan benih (Efendie, 2002), pengamatan dilakukan setiap 2 minggu sekali. Untuk kualitas air meliputi : amonia, nitrit, $\mathrm{DO}, \mathrm{pH}$, suhu dan alkalinitas sebagai data pendukung diamati satu bulan sekali.

Nikolsky dalam effendie (1978) meguraikan tingkat kematangan ovari ikan secara umum :

Tahap I : Tahap muda (immature), individu-individu muda belum mempunyai keinginan reproduksi dan ukuran ovari sangat kecil.

Tahap II : : Tahap istirahat (resting stage)ovari belum berkembang dan ukuranya sangat kecil

Tahap III : Proses pemsakan (maturration), pertambahan berat gonad sangat cepat, ovari berubah dari trasnparan ke pucat. Telur dapat dibedakan dengan mata.

Tahap IV : Masak (maturity), produk seksul sudah mencapai berat maksimum tetapi belum bisa keluar saat perut ditekan perlahan.

Tahap V : Reproduksi (reproduction) produk sexual akan keluar bila perut ditekan perlahan, berat gonafd trurun drastis mulai dari awal pemijahan sampai selesai. 
Tahap VI $\quad$ Kondisi salin (spent condition), produk sexual telah dikeluarkan, lubang genital
$\quad$ meredang kemerahan, gonad telah mengempis dan ovari berisi beberapa telur tersisa Tingkat istirahat (resting stage) :

$$
\mathrm{S}=\underline{\mathrm{Nt}} \times 100 \%
$$

No

Keterangan :

$\mathrm{S}=$ persentase kelangsungan hidup ikan (\%).

$\mathrm{Nt}=$ jumlah ikan akhir penelitian (ekor).

No = jumlah ikan awal penelitian (ekor).

\section{Rancangan Percobaan}

Rancangan penelitian disusun berdasarkan Rancangan Acak Lengkap (RAL)

dengan empat perlakuan yang diulang sebanyak empat kali

Model Statistik : Steel and Torrie (1991)

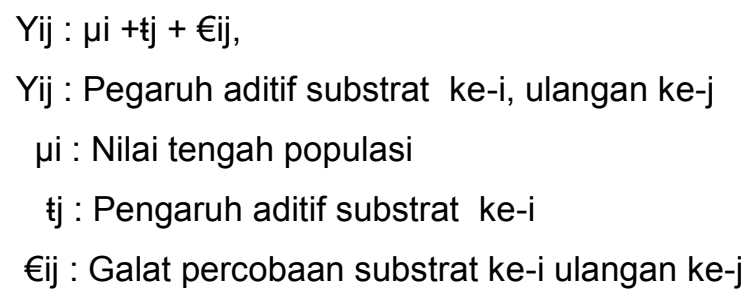

\section{Analisis Data}

Data yang diperoleh yaitu : kualitas air, histologi dianalisa secara deskriptif dalam bentuk grafik dan tabel. Data untuk : induk matang gonad, reproduksi, sintasan, pertumbuhan dan FCR di uji sidik ragam (ANOVA) dan analisis lanjut dengan uji LSD (uji t) program SPSS versi 12.0.

\section{HASIL DAN PEMBAHASAN}

Kematangan Gonad

Proses kematangan gonad dipengaruhi oleh kerja vitologenin yang menyebabkan GSI meningkat. Proses sisntesis vitologenin terjadi di organ hati, setelah vitologenin matang akan dilepaskan ke dalam plasma kemudian sistem peredaran darah mengirimnya ke ovari selanjutnya diarahkan ke berbagai lokasi kuning telur di dalam oosit. 


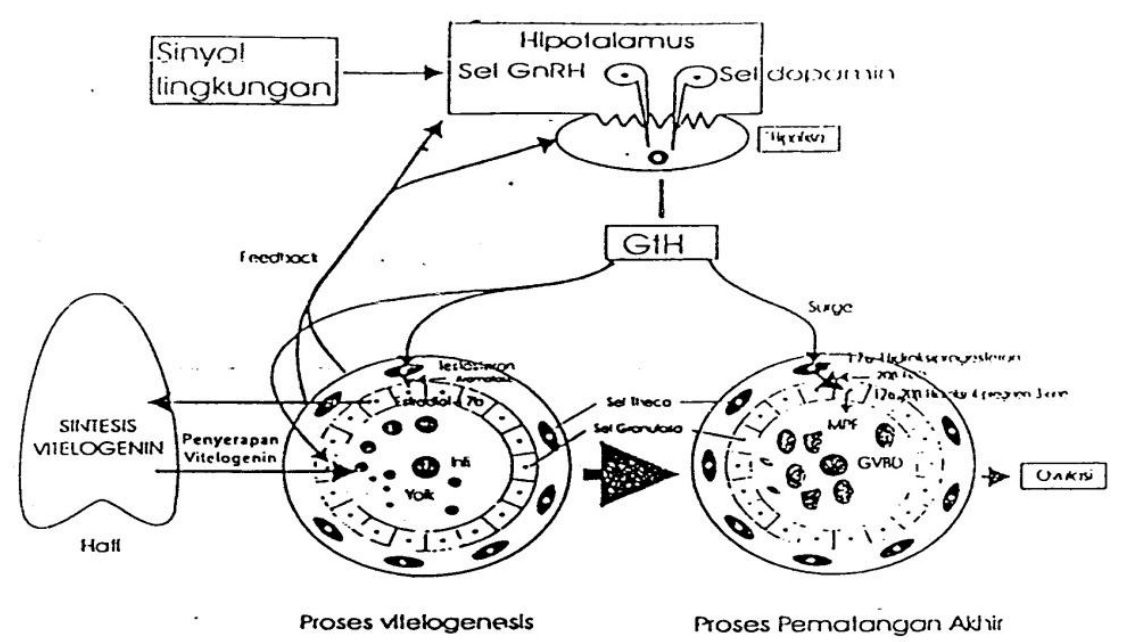

Gambar 1. Kontrol hormon pada proses reproduksi ikan (Aida et al., 1991)

Sinyal lingkungan berpengaruh terhadap sistem syaraf dimana adanya substrat yang terlihat ikan akan menyebabkan syaraf mengirim sinyal ke kelenjar hipotalamus. Kelenjar hipothalmus akan mengintrusikan proses vitologenin berjalan kemudian di sebarkan melalui peredaran darah untuk merangsang pembentukan sel telur sampai matang dan ovulasi. Selengkapnya pengaruh sinyal lingkungan terhadap proses hormon selama tahap reproduksi dijelaskan di Gambar 1.

\section{Kematangan Sperma}

Siklus reproduksi menurut Van Oordit et al. (1987), dibagi ke dalam tiga periode yaitu; 1. periode perkembangbiakan, 2. istirahat dan 3. pembentukan gamet. Pada ikan Clarias gariepinus jantan periode perkembangbiakan terjadi bulan mei-agustus ditandai dengan kenaikan dan penurunan gonadosomatik indeks (GSI). Tahap sebelum pemijahan tubulus testis terdiri dari siste-siste yang berisi spermatogonia B dan spermatosist primer. Periode istirahat Agustus-Maret, selama itu GSI relatif rendah pada tahap ini terjadi proses perkembangan testikular. Periode pertumbuhan gamet berlangsung di bulan Maret-Mei ditandai dengan aktifitas spermatogenik secara kontinu dan nilai GSI meningkat. Hasil percobaan substrat melati air menunjukkan GSI meningkat dan sampai pada kematangan telur yang cukup untuk ovulasi, hal ini dikuatkan pada bulan Juli ikan Rasbora yang dipelihara dengan substrat melati air memijah.

\section{Kematangan Oosit}

Setelah pertumbuhannya oosit sempurna ia siap mengalami pembelahan reduksi, inti akan berada di tengah setelah matang akan kepinggir sebelum terjadi ovulas. Pengamatan selanjutnya dilakukan dengan analisa histologi terhadap induk Rasbora sp. Hasil analisa histologi menjelaskan setelah terjadi pemijahan/ovulasi ditunjukkan dengan adanya telur masih TKG I dimana oocyte masih belum jelas dan warna telur masih unggu. Hal ini sejalan setelah terjadi pemijahan/ovulasi sel telur akan tumbuh lagi untuk siap melakuka pemijahan selanjutnya. Selengkapnya hasil analisa histologi selama percobaan di jelaskan di Gambar 2. 

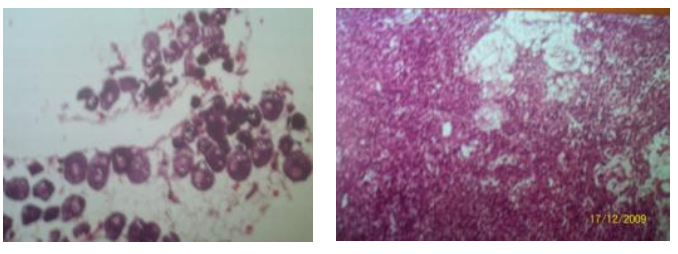

a.
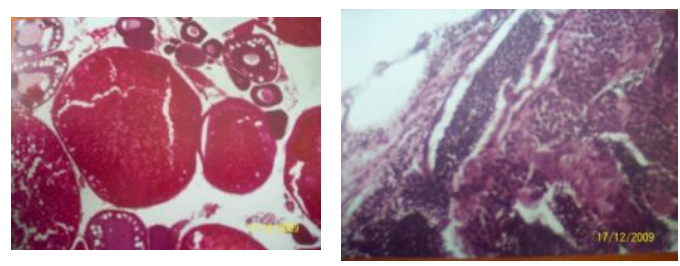

C.
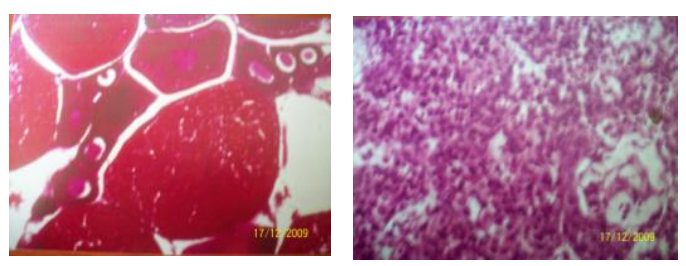

b.
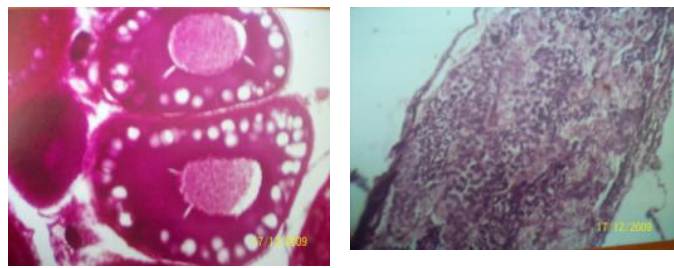

d.

Gambar 2. Hasil histologi gonad Rasbora sp, untuk setiap substrat selama percobaan A. Eichornia crassipes, B. hidryla, C. melati air dan D. tali plastik.

\section{Mekanisme Ovulasi}

Mekanisme ovulasi selain dipengaruhi faktor dari dalam juga dipengaruhi faktor dari lur antara lain fotoperiode, temperatur, substrat dan visual serta kimiawi. Media substrat penting dalam pemijahan terutama dalam pengaturan ovulasi dan setiap spesies membutuhkan substrat yang berbeda. Sebagai contoh Lutjanus campechaus dan Sparus auratus membutuhkan substrat berbatu. Menurut Tang (2000), rangsangan visual di peroleh ikan sepat akan cepat berovulasi jikan ada pembukaan sarang yang dibuat oleh jantan, sedangkan gurameh akan berovulasi setelah sarang yang dibangun untuk meletakan telur selesai.

\section{PEMIJAHAN}

Pemijahan terjadi apabila beberapa faktor pendukung sebagai triger terpenuhi untuk melakukan reproduksi, diantara faktor tersebut adalah kondisi lingkungan yang mendukung. Menurut Efendie (2003), faktor lain yang mendukung ikan bereproduksi adalah tersedianya pakan dan lingkungan yang optimum. Pengaruh pakan terhadap perkembangan gonad di laporkan oleh Lovell (1988), dimana ikan Channel catfish sangat dipengaruhi keseimbangan komposisi nutrisi pakan. Menurut Watanabe et al. (1984) kadar protein $45 \%$ baik untuk reproduksi red sea bream dan 36\% untuk rainbow trout. Pakan yang diberikan selama pematangan gonad dan pemijahan adalah Chironomus, selain faktor nutrisi faktor lingkungan seperti substrat juga berpengaruh terhadap pemijahan ikan.

Manipulasi lingkungan yang diberikan selama penelitian adalah pemberian substrat yang berbeda untuk tempat menempelkan telur selama pemijahan. Hasil percobaan substrat melati air menunjukkan GSI meningkat dan sampai pada kematangan telur yang cukup untuk ovulasi, hal ini dikuatkan pada bulan Juli ikan Rasbora yang dipelihara dengan substrat melati air memijah. Selama 
percobaan pengamatan pembenihan terutama saat pembelahan sel tidak teramati, karena pemijahan diketahui saat larva sudah berenang. Menurut Husnah dan Arsyad (2009), Telur Rasbora sangat kecil dan berwarna bening transparan sehingga untuk mengamati relatif susah. telur rasbora termasuk kelompok telur dengan ukuran kecil dengan diameter telur antara 0.27-0.37 mm dengan jumlah telur 200 butir/gram gonad.

\section{Pertumbuhan}

Pertumbuhan ikan dipengaruhi oleh beberapa hal dintaranya pakan dan kondisi lingkungan. Dengan kondisi lingkungan yang optimal untuk pertumbuhannya dan makanan yang tercukupi untuk memenuhi energi bagi pemeliharaan tubuh menyediakan energi yang lain untuk pertumbuhan dan reproduksi.

\section{Panjang Total}

Menurut Effendie (2003), energi yang berasal dari pakan selain untuk pertumbuhan bobot digunakan juga untuk pertambahan panjang. Hasil penelitian menunjukkan bahwa semua perlakuan cenderung mengalami pertambahan panjang selama pemeliharaan yang dapat dilihat pada Gambar 2 . Selengkapnya pertumbuhan panjang tertinggi diperoleh perlakuan A. $1.46 \mathrm{~cm} / \mathrm{ekor}$, diikuti perlakuan D. $0.85 \mathrm{~cm}$, B. $0.70 \mathrm{~cm} /$ ekor dan C. $0.44 \mathrm{~cm} / \mathrm{ekor}$.

Bila dibandingkan dengan pertumbuhan (pertambahan bobot) maka pada penelitian ini berlaku pertumbuhan ikan lebih cenderung ke pertambahan panjang dari pada pertambahan bobot. Hal ini didukung oleh Effendie (2003) bahwa keadaan ikan akan dikatakan kurus apabila pertumbuhan panjang lebih cepat dibandingkan pertumbuhan bobot dan akan dikatakan gemuk apabila pertumbuhan bobot lebih cepat dibandingkan pertambahan panjang.

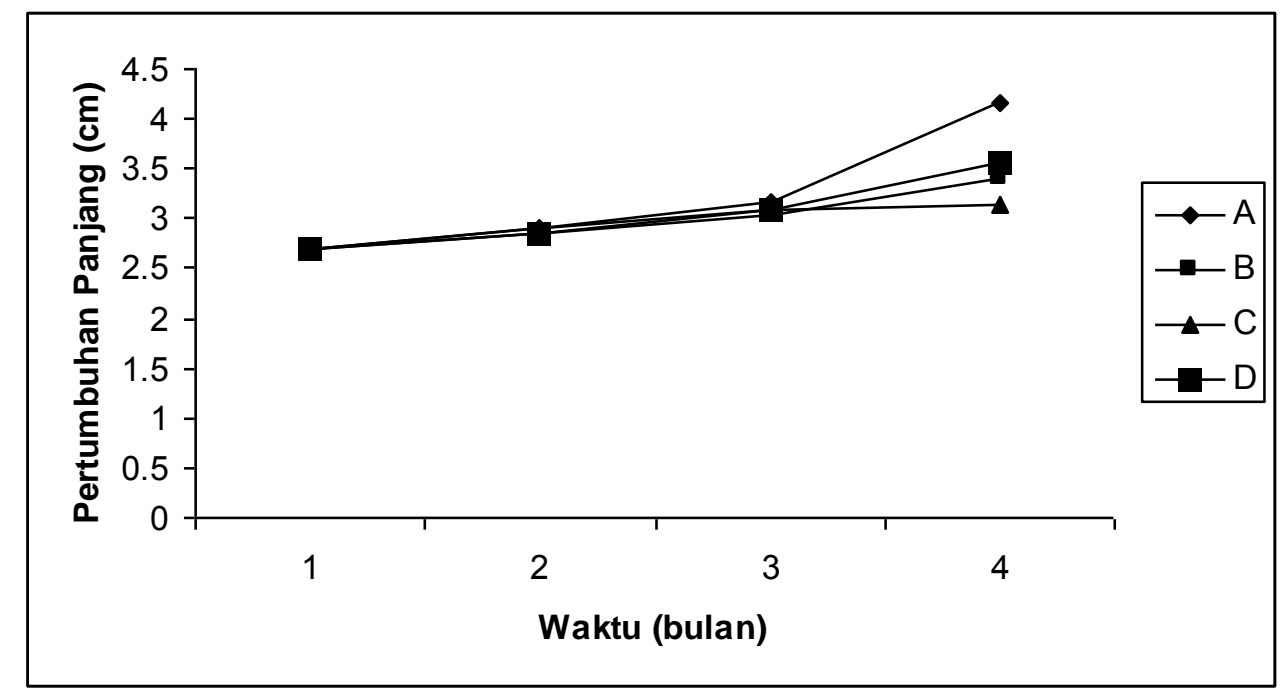

Gambar 2. Pertambahan panjang total individu ikan Rasbora sp. selama pemeliharaan

Selain kualiatas air yang mendukung, diperlukan juga asupan nutrisi selama proses pertumbuhan dan perkembanganya. 


\section{Bobot (gram)}

Hasil penelitian untuk pertumbuhan mutlak individu Rasbora sp grafiknya cenderung naik menunjukkan adanya pertumbuhan selama pemeliharaan. Selengkapnya pertumbuhan bobot tertinggi diperoleh perlakuan B. dan C dengan berat 0.07 gram/ekor diikuti A. 0.06 gram/ekor dan D. 0.04 gram/ekor. Selengkapnya pertumbuhan bobot selama percobaan di sajikan di Gambar 3.

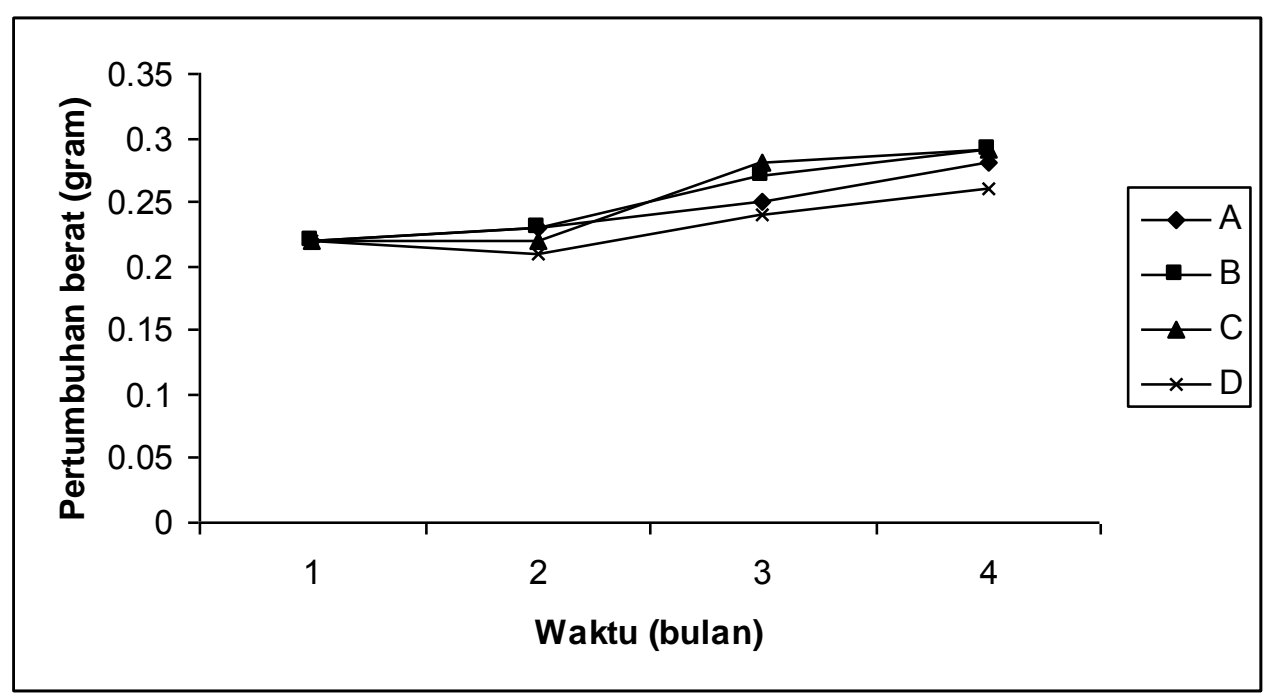

Gambar 3. Grafik Pertumbuhan mutlak individu ikan Rasbora sp. selama pemeliharaan enam bulan di akuarium

Menurut Lovell (1989) bahwa pertumbuhan akan terjadi apabila ada kelebihan energi bebas setelah energi yang tersedia dipakai untuk pemeliharaan tubuh dan aktivitas. Selain itu kondisi lingkungan, kemampuan cerna dan komposisi pakan juga mempengaruhi pertumbuhan sedangkan menurut Mudjiman (2004), dan Fujaya (1994), tiap jenis ikan memiliki waktu yang berbeda-beda dalam pertumbuhannya.

\section{Sintasan}

Hasil yang diperoleh selama penelitian mengenai sintasan data yang diperoleh berbeda antar perlakuan, hal ini menunjukan filter yang digunakan berpengaruh terhadap sintasan benih Rasbora sp. Adapun hasil sintasan yang diperoleh di akhir penelitian yaitu tali plastik 83.33\% diikuti oleh ganggang $80.6 \%$, enceng gondok $53.3 \%$ dan tanaman air $47.8 \%$. Selengkapnya nilai sintasan selama pemeliharaan disajikan di Gambar 4. 


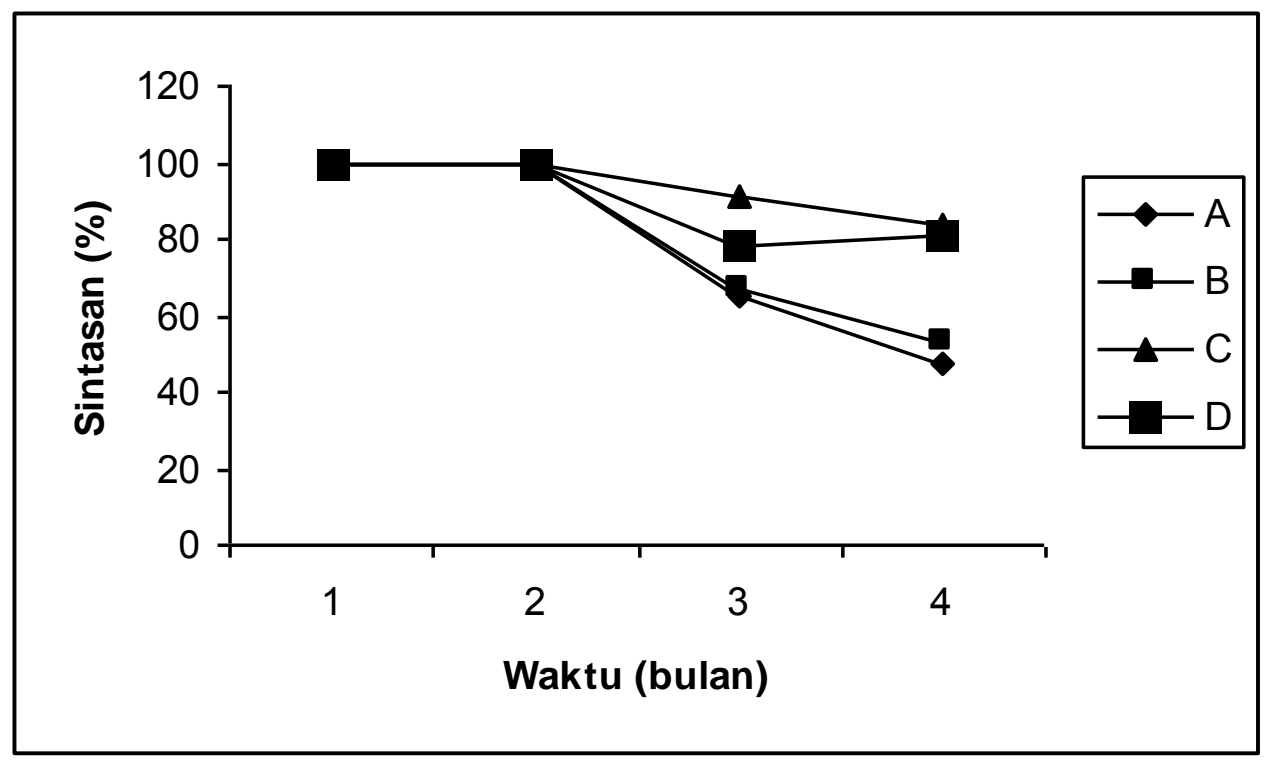

Gambar 4. Grafik sintasan ikan Rasbora sp. selama pemeliharaan di akuarium

Menurut Fadhilah (2006) bahwa kelangsungan hidup individu sangat ditentukan oleh ketersediaan pakan dan kemampuan individu tersebut beradaptasi dengan lingkungannya dan Pregiwati (2000), faktor yang mempengaruhi kelangsungan hidup meliputi lingkungan, predator, dan sumber pakan.

\section{Kualitas Air}

Kualitas air yang baik sebagai input lanjutan bagi ikan yang dipelihara, sehingga proses metabolisme meningkat dan menghasilkan energi yang diperlukan untuk pemeliharaan dan pertumbuhan. Salah satu penentu keberhasilan proses perbaikan kualitas air ditentukan oleh beberapa parameter penting dengan batas nilai kriteria berdasarkan tujuan penggunaannya.

Analisa kualitas air dilakukan setiap bulan selama pemeliharaan, parameter suhu dapat mempengaruhi aktivitas penting ikan terutama untuk pernapasan, pertumbuhan dan reproduksi. Pengamatan suhu selama penelitian menunjukkan kisaran antara $26-27^{\circ} \mathrm{C}$ yang menunjukkan kisaran suhu berada pada kisaran optimal untuk pertumbuhan Rasbora sp. (Brittan 1953). Selengkapnya hasil analisa kualitas air selama percobaan di sajikan di Tabel 1.

Tabel 1. Beberapa parameter kualitas air dan batas rekomendasi

\begin{tabular}{|c|c|c|c|c|c|c|}
\hline \multirow{2}{*}{$\begin{array}{l}\text { Para- } \\
\text { meter }\end{array}$} & \multirow{2}{*}{$\begin{array}{l}\text { Rekomen- } \\
\text { dasi }\end{array}$} & \multicolumn{4}{|c|}{ Pengukuran } & \multirow[t]{2}{*}{ Pustaka } \\
\hline & & $\bar{A}$ & $\mathrm{~B}$ & $\mathrm{C}$ & $\mathrm{D}$ & \\
\hline Suhu $\left({ }^{0} \mathrm{C}\right)$ & $25-29$ & $26-30$ & $26-30$ & $26-29$ & $25-31$ & Boyd, 1990 \\
\hline $\mathrm{Ph}$ & $6-9$ & $7.1-8.4$ & $7.0-8.3$ & $7.0-8.2$ & $7.0-8.8$ & $\begin{array}{l}\text { Wedemeyer, } 1996 \\
\text { Boyd, } 1990\end{array}$ \\
\hline $\mathrm{DO}(\mathrm{mg} / \mathrm{l})$ & $>4$ & $4.58-10.23$ & $\begin{array}{l}46.00- \\
09.18\end{array}$ & $6.71-8.12$ & $6.35-8.16$ & $\begin{array}{l}\text { Wedemeyer, } 1996 \\
\text { Boyd, } 1990\end{array}$ \\
\hline $\mathrm{NH}_{3}(\mathrm{mg} / \mathrm{l})$ & $<0.02$ & 0.008 & 0.003 & 0.0042 & 0.00694 & $\begin{array}{l}\text { Wedemeyer, } 1996 \\
\text { Pescod, } 1973\end{array}$ \\
\hline $\mathrm{NO}_{2}(\mathrm{mg} / \mathrm{l})$ & $<0.1$ & 0.0005 & 0.0005 & 0.007 & 0.008 & Wedemeyer, 1996 \\
\hline
\end{tabular}




\begin{tabular}{|l|l|l|l|l|l|l|}
$\mathrm{NO}_{3}(\mathrm{mg} / \mathrm{l})$ & $<1.0$ & 0.037 & 0.077 & 0.064 & 0.070 & Wedemeyer, 1996 \\
\hline
\end{tabular}

Hasil pengukuran $\mathrm{pH}$ air selama penelitian berkisar antara 4.5-7.0. Berdasarkan data tersebut dapat dikatakan $\mathrm{pH}$ air selama penelitian adalah $\mathrm{pH}$ optimal untuk menunjang pertumbuhan dan kelangsungan hidup Rasbora sp. Kandungan oksigen terlarut selama penelitian berada pada kisaran 6.71-10.59 ppm. Menurut Zonneveld (1991) jika kadar oksigen terlarut rendah ( $<3$ ppm) akan mengakibatkan nafsu makan berkurang dan jika nilainya sangat rendah dalam jangka waktu yang lama maka ikan akan berhenti makan dan pertumbuhannya akan terhenti.

Hasil pengukuran kandungan oksigen terlarut selama percobaan adalah 5.64-10.23 mg/l, setiap media filter mempunyai konsentrasi oksigen yang cukup. Konsentrasi oksigen yang tinggi di setiap perlakuan dikarenakan semua filter diberikan aerasi. Hasil pengukuran konsentrasi oksigen selama percobaan masih pada kisaran yang layak untuk kehidupan biota air. Menurut Wedemeyer (1996), batas terendah oksigen terlarut yang baik untuk kehidupan ikan adalah $>4 \mathrm{mg} / \mathrm{l}$.

\section{KESIMPULAN}

Hasil penelitian menunjukkan pertambahan panjang tertinggi diperoleh perlakuan A. 1.46 cm/ekor, diikuti perlakuan D. $0.85 \mathrm{~cm}$, B. $0.70 \mathrm{~cm} / \mathrm{ekor}$ dan C. $0.44 \mathrm{~cm} / \mathrm{ekor}$. Sedangkan pertumbuhan bobot tertinggi diperoleh perlakuan B. dan C dengan berat 0.07 gram/ekor diikuti A. 0.06 gram/ekor dan D. 0.04 gram/ekor. Selama pemeliharaan diperoleh nilai sintasan yang diperoleh di akhir penelitian yaitu tali plastik $83.33 \%$ diikuti oleh ganggang $80.6 \%$, enceng gondok $53.3 \%$ dan tanaman air $47.8 \%$. Kualitas air selama pemeliharaan masih dalam kisaran yang baik untuk ikan Rasbora sp. Bulan kelima pemelihraan ikan dengan substrat tali plastik memijah namun benih yang dihasilkan masih sedikit hal ini dikarenakan ikan yang memijah sudah masuk masa tidak produktif.

\section{DAFTAR PUSTAKA}

Brittan MR. 1953. Rasbora. A. Rivision of the Indo-Malayan Fresh-Water Fish Genus Rasbora, with natural color photographs.

Boyd, C.E and C. Tucker. 1990. Water Quality and Pond Soil Analysis for Aquaculture. Departement of Fisheries and Allied Agriculture, Agricultural Station Auburn University. Auburn.

Simon \& Schuster's 2005. Guide to Freshwater and Marine Aquarium. Simon \& Schuster's Inc. New York: 563p.

Effendie, M.I. 1979. Biologi Perikanan I. Studi Natural History. Fakultas Perikanan. IPB. Bogor

Effendie MI. 2002. Biologi Perikanan. Yayasan Pustaka Nusatama. Yogyakarta.

Fadhlillah, Liza. 2006. Pengaruh Padat penebaran Rasbora heteromorpha Terhadap Pertumbuhan Rasbora heteromorpha dan Kelangsungan Hidup Benih

Fujaya, Y. 1994. Fisiologi Ikan, Dasar Pengembangan Teknologi Perikanan. Jakarta:

Husnah dan M. N. Arsyad. 2009. Keragaman jenis, sebaran, habitat dan karakter biologi ikan seluang (Rasbora sp) di perairan umum. Universitas PGRI Palembang. Palembang.

Kottelat. 1995. Freswater Fishes of Western Indonesia and Sulawesi. 293 hal. 
Lesmana, D. S. 2005. Kualitas Air Untuk Ikan Hias Air Tawar. Jakarta: Penebar Swadaya.

Lovell, R. T. 1989. Nutrition and Feeding on Fish. Van Nostrand Reinhold Publishing. New York:260 hlm.

Mills Dick. 2000. The Encyclopedia of Aquarium Fish. Singapore: Periplus Edition (HK) Ltd.

Mudjiman, A. 2004. Makanan Ikan. Jakarta : Penebar Swadaya

Pregiwati, L. A. 2000. Pengaruh Padat Penebaran Terhadap Produksi Udang Windu (Penaeus monodon Fab) Secara Intensif dengan Rasio Luas Petak Perlakuan dan Petak Pembesaran yang Berbeda. Skripsi. Fakultas Perikanan dan Ilmu Kelautan. Institut Pertanian Bogor. Tidak dipublikasikan.

Samuel, Prasetyo, D., dan Akrini. 1995. Distribusi dan beberapa aAxelrodyek biologi ikan balashark

(Balashark macracanthus) di DAS Batanghari, Jambi. Prosiding Seminar Hasil Penelitian Perikanan

Air tawar 1993/1994 Balai Penelitian Perikanan Air tawar, Sukamandi. Hal. 108-116.

Steel RGD and Torrie, JH. 1991. Principles and Procedures of Statistics. A Biometrical approach. Seconded. Mc. Graw Hill International Book Company. Sydney.

Satyani, D., Priyadi, A., Subandiyah, S.,Kadarini, T., dan Subagja, J. Peningkatan keberhasilan kematangan gonad dan ovulasi ikan balashark (Balashark macracanthus). Laporan Hasil Riset Perikanan Air Tawar tahun 2002, Balai Riset Perikanan Budidaya Air Tawar . 6 Hal.

Simon \& Schuster's: Guide to Freshwater and Marine Aquarium. Simon \& Schuster's Inc. New York: $563 \mathrm{p}$.

Steel, R. G. D. and Torrie, J. H. 1991. Principles and Procedures of Statistics. A Biometrical approach. Seconded. Mc Graw Hill International Book Company. Sydney.

Wedemeyer, G. A. 1996. Physiology of fish in intensive culture system. Chapman and Hall. Printed in the united Stated of Amaerika. 232 sp.

Zonneveld, Huisman dan Bond. 1991. Prinsip-Prinsip Budidaya ikan. Jakarta: Gramedia Pustaka Utama 